\title{
Impact of biomass burning on ocean water quality in Southeast Asia through atmospheric deposition: field observations
}

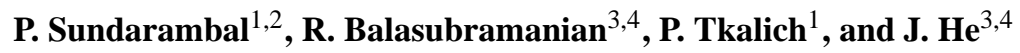 \\ ${ }^{1}$ Tropical Marine Science Institute, National University of Singapore, 14 Kent Ridge Road, 119223, Singapore \\ ${ }^{2}$ Department of Chemical and Biomolecular Engineering, National University of Singapore, 117576, Singapore \\ ${ }^{3}$ Division of Environmental Science and Engineering, National University of Singapore, 117576, Singapore \\ ${ }^{4}$ Singapore Delft Water Alliance, National University of Singapore, Engineering Drive 1, 117576, Singapore
}

Received: 27 February 2010 - Published in Atmos. Chem. Phys. Discuss.: 25 March 2010

Revised: 13 August 2010 - Accepted: 7 September 2010 - Published: 1 December 2010

\begin{abstract}
Atmospheric nutrients have recently gained considerable attention as a significant additional source of new nitrogen $(\mathrm{N})$ and phosphorus $(\mathrm{P})$ loading to the ocean. The effect of atmospheric macro nutrients on marine productivity depends on the biological availability of both inorganic and organic N and P forms. During October 2006, the regional smoke haze episodes in Southeast Asia (SEA) that resulted from uncontrolled forest and peat fires in Sumatra and Borneo blanketed large parts of the region. In this work, we determined the chemical composition of nutrients in aerosols and rainwater during hazy and non-hazy days to assess their impacts on aquatic ecosystem in SEA for the first time. We compared atmospheric dry and wet deposition of $\mathrm{N}$ and $\mathrm{P}$ species in aerosol and rainwater in Singapore between hazy and non-hazy days. Air mass back trajectories showed that large-scale forest and peat fires in Sumatra and Kalimantan were a significant source of atmospheric nutrients to aquatic environments in Singapore and SEA region on hazy days. It was observed that the average concentrations of nutrients increased approximately by a factor of 3 to 8 on hazy days when compared with non-hazy days. The estimated mean dry and wet atmospheric fluxes $\left(\mathrm{mg} / \mathrm{m}^{2} /\right.$ day) of total nitrogen (TN) were $12.72 \pm 2.12$ and $2.49 \pm 1.29$ during non-hazy days and $132.86 \pm 38.39$ and $29.43 \pm 10.75$ during hazy days; the uncertainty estimates are represented as 1 standard deviation $(1 \sigma)$ here and throughout the text. The estimated mean dry and wet deposition fluxes $\left(\mathrm{mg} / \mathrm{m}^{2} /\right.$ day) of total phosphorous (TP) were $0.82 \pm 0.23$ and $0.13 \pm 0.03$
\end{abstract}

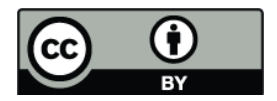

Correspondence to: R. Balasubramanian (eserbala@nus.edu.sg) for non-hazy days and $7.89 \pm 0.80$ and $1.56 \pm 0.65$ for hazy days. The occurrences of higher concentrations of nutrients from atmospheric deposition during smoke haze episodes may have adverse consequences on receiving aquatic ecosystems with cascading impacts on water quality.

\section{Introduction}

Enrichment of nutrients in aquatic ecosystems can lead to undesirable effects including algal blooms and depletion of oxygen in the water. Among sources of nutrients to aquatic ecosystems, atmospheric deposition ("wet atmospheric deposition (WAD)" and "dry atmospheric deposition (DAD", Fig. 1) is least understood despite its significance; the the supplementary material provides more details. Atmospheric inputs of nutrients (nitrogen $(\mathrm{N})$, phosphorus $(\mathrm{P})$ species and iron) have been hypothesized to play an important role in the chemical and biological dynamics of open oceans and aquatic ecosystems although delivered as a diffuse flux in contrast to localized river inputs (Menzel and Spaeth, 1962; Duce, 1986; Duce et al., 1991; Prospero et al., 1996; Spokes et al., 2000; Whitall et al., 2003). The role of atmospheric inputs as an annual source of nutrients to the euphotic zone has recently been evaluated (Duce, 1986; Duce et al., 1991; Hasager, 2003; Duce et al., 2008). Increasing quantities of atmospheric fixed $\mathrm{N}$ of anthropogenic origin, entering the open ocean, could account for up to about a third of the ocean's external (non-recycled) N supply and up to $3 \%$ of the annual new marine biological production (Duce et al., 2008). Atmospheric inputs of bioavailable $\mathrm{N}$ and $\mathrm{P}$ reinforce the unusual N:P ratios, and can lead to possible P limitation

Published by Copernicus Publications on behalf of the European Geosciences Union. 


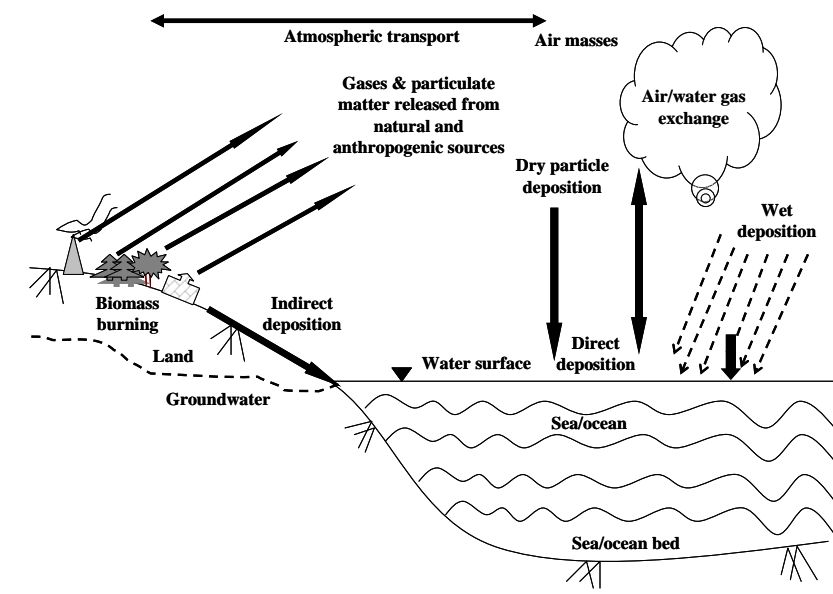

Fig. 1. A schematic illustration of atmospheric deposition processes.

as has been documented in the Mediterranean Sea (Herut et al., 1999; Thingstad et al., 1998; Krom et al., 1991). It should also be noted that as human activities continue to preferentially increase N deposition (e.g. Galloway et al., 1994), ocean ecosystems may shift from $\mathrm{N}$ limitation to limitation by other nutrients (e.g. phosphorus) or trace elements.

Biomass burning is an important source of nutrients and numerous trace elements, especially in Southeast Asia (SEA), where the smoke haze phenomenon is a major and recurring problem (Balasubramanian et al., 1999, 2003; Zhong et al., 2001; Balasubramanian and Qian, 2004). To date, there has been no systematic study to estimate the atmospheric deposition of nutrients in SEA despite recurring forest and peat fires in the region. Atmospheric fluxes of nutrients, derived from biomass burning, could contribute a substantial fraction of dissolved $\mathrm{N}$ or $\mathrm{P}$ species to the euphotic zone, and enhance primary production, when nutrients are limited, leading to eutrophication. Quantified atmospheric inputs of nutrients are therefore needed for development and validation of water quality models and for estimation of pollution loading budgets. $\mathrm{N}$ is usually considered as the limiting nutrient in the oceans, although $\mathrm{PO}_{4}^{3-}$ or even trace metals may also play a role in regulating phytoplankton growth. Gin et al. (2006) reported that Singapore waters were generally $\mathrm{N}$ limited. However, the variable anthropogenic inputs and a N:P ratio close to the Redfield ratio imply that nutrient limitation can easily switch to phosphorus. Water quality models with the capability of simulating such scenarios in terms of shifts in the N:P ratio can provide insights into the effects of nutrient deposition on aquatic ecosystems.

The present study is focused on quantification of water soluble nutrients ( $\mathrm{N}$ and $\mathrm{P}$ species only) resulting from DAD (aerosol particulates) and WAD (rainwater) in SEA for the first time. Quantification of iron and its impact on eutrophication is currently being studied and will be reported elsewhere. In this study, observational data were collected to estimate DAD and WAD fluxes of $\mathrm{N}$ and $\mathrm{P}$ species during hazy and non-hazy days to the coastal waters in Singapore. The atmospheric nutrients analyzed were: $\mathrm{N}$ species such as ammonium $\left(\mathrm{NH}_{4}^{+}\right)$, nitrate $\left(\mathrm{NO}_{3}^{-}\right)$, nitrite $\left(\mathrm{NO}_{2}^{-}\right)$, total nitrogen (TN) and organic nitrogen $(\mathrm{ON})$, and $\mathrm{P}$ species such as phosphate $\left(\mathrm{PO}_{4}^{3-}\right)$, total phosphorous (TP) and organic phosphorous (OP). A selected number of DAD samples, 4 and 16 for the hazy and non-hazy days, respectively, are presented in this article. This work represents the first study of its kind focused on bringing together field-based investigations to quantify atmospheric nutrient deposition (the present article) and eutrophication modeling (presented in a companion article, Sundarambal et al., 2010) to investigate the impact of atmospheric nutrient deposition on coastal water quality and provide a scientific basis for a more in-depth future study in this region.

\section{Materials and methods}

\subsection{Experimental}

\subsubsection{Sampling location}

Singapore is a small island with total land area of $710 \mathrm{~km}^{2}$ located at latitudes between $1^{\circ} 06^{\prime} \mathrm{N}$ and $1^{\circ} 24^{\prime} \mathrm{N}$ and longitudes between $103^{\circ} 24^{\prime} \mathrm{E}$ and $104^{\circ} 24^{\prime} \mathrm{E}$ (Fig. 2). It is highly urbanized and industrialized with small water resources and limited ocean environment surrounding the island. Because of its geographical location, Singapore's climate is characterized by uniform temperature and pressure, high humidity and abundant rainfall throughout the year. Singapore has two main seasons, the Northeast Monsoon (NEM) (November to March) and the Southwest Monsoon (SWM) season (June to September), separated by two relatively shorter inter-monsoon (IM) periods (April to May and October, respectively). The ambient air temperature ranges from 21.1 to $35.1^{\circ} \mathrm{C}$, and the annual average rainfall is $2136 \mathrm{~mm}$. The population of Singapore is 4.99 million (Singapore Department of Statistics, 2009). Southwest (SW) and Northeast (NE) winds occur in the coastal area periodically, with the mean daily maximum wind speeds ranging from $5 \mathrm{~m} / \mathrm{s}$ to $10 \mathrm{~m} / \mathrm{s}$. Both aerosol and rainwater samples were collected at the Tropical Marine Science Institute in St. John's Island (SJI), Singapore (Fig. 2). This island is geographically located at latitude of $1^{\circ} 13^{\prime} 10^{\prime \prime} \mathrm{N}$ and the longitude $103^{\circ}$ $50^{\prime} 54^{\prime \prime} \mathrm{E}$. There are no industrial air pollution sources close to the sampling site. This sampling station in SJI was selected as it is near the open coastal area in the southern part of Singapore and does not have local pollution sources. Except on regional hazy days, the air is free from major air pollution. In this study, the DAD and WAD samples collected at the SJI station during hazy and non-hazy days were analyzed. 


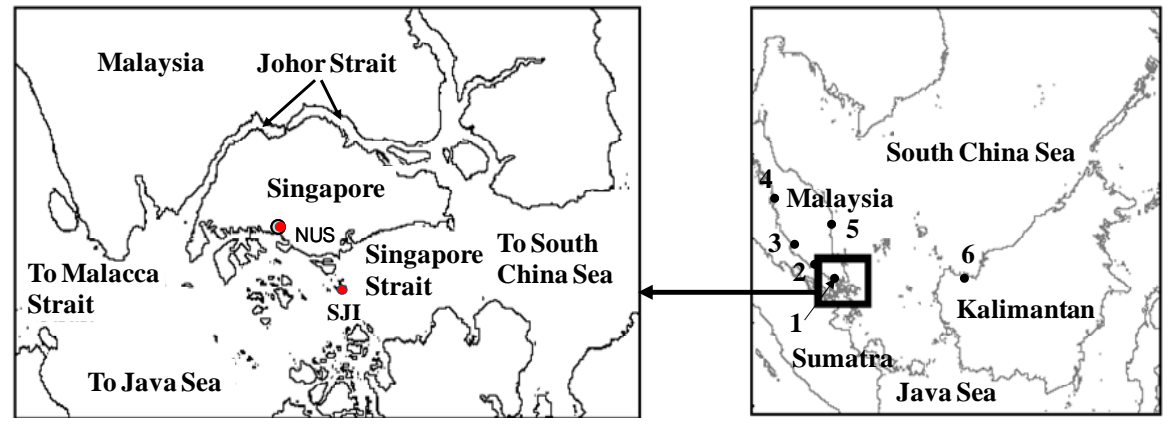

Fig. 2. Map showing sampling locations in Singapore and surrounding regions. Note: 1. Johor Bahru, 2. Malacca Town, 3. Kuala Lumpur, 4. George Town, 5. Kuantan and 6. Kuching.

\subsubsection{Sample collections}

The total suspended particulates (TSP) have been widely measured for the characterization of their elemental composition and nutrients for estimation of dry deposition fluxes (Caruso et al., 1981; Herut et al., 1999; Duarte et al., 2006; Chen et al., 2007; Ayars and Gao, 2007). The TSP samples were collected using a High Volume Air Sampler (HVAS, model 3800 AFC: HI-Q Environmental Products Company, USA). The air flow in HVAS was maintained at 40 SCFM (Standard Cubic Feet per Minute) by an automatic air flow control device. For collection of TSP samples, Whatman QM-A Quartz air-sampling filters of $20.3 \times 25.4 \mathrm{~cm}$ size were used. All filters used in this study were inspected for defects under bright illumination. All blank filters and filter samples were handled with a pair of stainless steel forceps. The filters were pre-equilibrated in a dry box with stabilized temperature $\left(22-25^{\circ} \mathrm{C}\right)$ and relative humidity $(30-35 \%)$ for at least $24 \mathrm{~h}$ before the actual weighing. Filters were then weighed using a MC5 microbalance (Sartorius AG, Goettingen, Germany) with a sensitivity of $0.0001 \mathrm{mg}$. The balance was regularly checked with NIST-traceable standard calibrated weights. TSP samples were collected every $24 \mathrm{~h}$ three times a week at the sampling location mainly during dry weather conditions for the characterization of water soluble ions and nutrients. The filters were folded in half lengthwise so that only surfaces with collected particulate matter were in contact, when placed in the filter holder (glassine envelope). The pre- and post-sampling weights were used to obtain the particulate mass collected on the filters. The TSP filters were stored in a refrigerator at $4{ }^{\circ} \mathrm{C}$ until extraction for sample analysis. Although storage of filter samples at $-20^{\circ} \mathrm{C}$ is optimum for long term preservation, it was observed that $4{ }^{\circ} \mathrm{C}$ is still sufficient for short term storage of nutrient samples (Karthikeyan and Balasubramanian, 2006; Karthikeyan et al., 2009a, b). The mass concentration of TSP $\left(\mu \mathrm{g} / \mathrm{m}^{3}\right)$ was calculated from the collected mass of particulates $(\mu \mathrm{g})$ divided by the volume of air passed through the filter $\left(\mathrm{m}^{3}\right)$ during sampling period.
Whenever there were rain events, the rainwater samples were collected by using an automated wet only rainwater sampler (Ecotech Model 200: Ecotech Pty Ltd, Australia) at the sampling location. The frequency of rain events that occurred during the biomass burning period was relatively less than that during the wet season. Rainwater samples were transferred from the sampler to pre-cleaned highdensity polyethylene (HDPE) bottles after the rain event and immediately filtered using $0.45 \mu \mathrm{m}$ nylon membrane filters and refrigerated at $4{ }^{\circ} \mathrm{C}$ for sample analysis. For precleaning, HPDE bottles $\left(250 \mathrm{~mL}\right.$, Nalgene $\left.{ }^{\circledR}\right)$ were filled with $2 \mathrm{~N} \mathrm{HNO}_{3}$ for 3 days and subsequently with ultrapure water for 3 days. Finally, they were rinsed with ultrapure water three times and kept safely in plastic bags until use. No residual $\mathrm{NO}_{3}^{-}$was found in the rinse water after washing (Karthikeyan et al., 2009a, b). Rainfall with less than $1 \mathrm{~mm}$ was not considered for laboratory analysis because such events yielded low or negligible nutrient loads even though the nutrient concentration was high (Bartoli et al., 2005). The following QA/QC procedures were used for both lab and field methods. Total sampling times, average actual volumetric flow rates, tare and gross-filter weights were checked for accuracy. Field blanks, obtained at regular intervals by placing filters in the filter holder with no air being drawn through them, were used to detect any contamination that may have occurred in the sample transport process. Likewise, laboratory blanks (unexposed filters) were also weighed and processed for quality assurance purposes. Both particulate and rainwater samples were collected using established methods as frequently as possible to study the impact of biomass burning on surface water quality through atmospheric deposition. Daily rainfall amounts and other meteorological parameters were obtained during the sampling period from September 2006 through January 2007 using an automated weather station maintained by the Department of Geography at the National University of Singapore (NUS). The precipitation amounts at the two sampling locations (NUS and SJI) were similar during major storm events as observed from our previous studies. Altogether, 55 aerosol particulate samples 
and 21 rainwater samples (collected on event-to-event basis) were collected during the sampling period, and the results obtained from this field study are presented in this paper.

\subsubsection{Reagents and standards}

For preparation of reagents and standards, ultrapure water (MilliQ ${ }^{\circledR}$ Gradient A 10 System, Millipore, USA) was used. All reagents were of analytical grade. Anionic standards of chloride $\left(\mathrm{Cl}^{-}\right), \mathrm{NO}_{2}^{-}, \mathrm{NO}_{3}^{-}$, and sulfate $\left(\mathrm{SO}_{4}^{2-}\right)$ and $\mathrm{NH}_{4}^{+}$were procured from AccuStandard, USA. Sodium hydroxide $(\mathrm{NaOH})$, potassium persulfate $\left(\mathrm{K}_{2} \mathrm{~S}_{2} \mathrm{O}_{8}\right)$, ethylenediaminetetraacetic acid (EDTA) $\left(\mathrm{C}_{10} \mathrm{H}_{16} \mathrm{~N}_{2} \mathrm{O}_{8}\right)$, glycine $\left(\mathrm{C}_{2} \mathrm{H}_{5} \mathrm{NO}_{2}\right)$, and urea $\left(\mathrm{CH}_{4} \mathrm{~N}_{2} \mathrm{O}\right)$ were obtained from Merck, Germany.

SRM 1648 (Urban Particulate Matter), obtained from National Institute of Standards and Technology (NIST, Gaithersburg, MD, USA), was used for validation of the methods for both $\mathrm{N}$ and $\mathrm{P}$ species analysis. This standard consists of natural atmospheric particulate matter collected at an urban location, and is certified for its major, minor, and traces inorganic constituents.

For ON, N standards were prepared from ETDA, urea, and glycine by dissolving appropriate amounts in ultrapure water in order to have a stock solution of $1000 \mathrm{mg} \mathrm{N} / \mathrm{L}$. EDTA-based standard $\mathrm{N}$ solution was used for optimization of microwave-assisted persulfate oxidation (Karthikeyan et al., 2009a). The other two reagents were used to check the robustness of the optimized procedure.

\subsubsection{Sample processing and analysis}

The aerosol particulate and rainwater samples were analyzed to characterize atmospheric wet and dry nutrient deposition as per the protocol developed in our laboratory (Sundarambal et al., 2006, 2009). The atmospheric nutrients analyzed in this study were: $\mathrm{N}$ species- $\mathrm{NH}_{4}^{+}, \mathrm{NO}_{3}^{-}, \mathrm{NO}_{2}^{-}, \mathrm{TN}$ and $\mathrm{ON}$, and $\mathrm{P}$ species- $\mathrm{PO}_{4}^{3-}$, TP and OP. A portion of filter samples ( $1 / 4$ or $1 / 8$ th portion of total filter area) was extracted with 20 or $50 \mathrm{ml}$ Milli-Q water (Millipore) in an ultrasonic bath at $60^{\circ} \mathrm{C}$ for $1 \mathrm{~h}$. The filter extracts from the ultrasonic bath were cooled to ambient temperature (room temperature $25^{\circ} \mathrm{C}$ ). The solution was then filtered through a $0.45 \mu \mathrm{m}$ polytetrafluoroethylene (PTFE) membrane syringe filter. Rainwater samples were taken after filtration for laboratory analysis. The rainwater and aerosol particulate samples were analyzed for the ionic species by ion chromatography (IC) (Model ICS-2000; Dionex Corporation) using a cation column and an anion column. TN and TP were analyzed according to our standard laboratory procedure (Karthikeyan et al., 2005a, b; Sundarambal et al., 2006; Karthikeyan and Balasubramanian, 2006; Karthikeyan et al., 2007, 2009a, b). Field and laboratory filter blanks were analyzed for the nutrients ( $\mathrm{N}$ and $\mathrm{P})$ species, and the values obtained for the blanks were subtracted from those of the filter samples. Both the quality assurance and quality control protocols were carried out regularly to avoid analytical errors in the laboratory measurements. The analytical quality of the data obtained was determined using important parameters such as limits of detection, recovery, linearity, and by eliminating sampling artifacts (Karthikeyan and Balasubramanian, 2006; Karthikeyan et al., 2009a, b).

\subsection{Deposition flux calculations}

\subsubsection{Dry deposition}

DAD is a slow, but continuous flux of airborne contaminants to an underlying surface. DAD fluxes $\left(F_{\text {dry }}\right.$ in $\mathrm{mg} / \mathrm{m}^{2} /$ day $)$ were calculated from the product of dry deposition velocity $\left(V_{\mathrm{d}}\right.$ in $\left.\mathrm{cm} / \mathrm{s}\right)$ and measured concentrations of nutrient species $\left(C_{\text {aerosol }}\right.$ in $\left.\mu \mathrm{g} / \mathrm{m}^{3}\right)$, as shown in Eq. (1) with unit conversion factor of 0.864 .

$F_{\text {dry }}=0.864 C_{\text {aerosol }} V_{\mathrm{d}}$

Deposition velocity, $V_{\mathrm{d}}$, may be viewed as the velocity at which pollutant gases and aerosols existing at a given atmospheric concentration are deposited to the Earth's surface. Processes that control $V_{\mathrm{d}}$ include gravitational settling, impaction, and diffusion. These processes act simultaneously and are affected by many variables including particle size, wind speed, relative humidity, and sea surface roughness. The term $V_{\mathrm{d}}$ is the result of many processes (for a full explanation see, e.g. Seinfeld and Pandis, 2006), and it is thus very difficult to determine. However, the calculation of $F_{\text {dry }}$ is usually carried out using $V_{\mathrm{d}}$ reported in the literature for many elements including nutrients (see e.g. Sehmel, 1980; Slinn and Slinn, 1980; William, 1982; Joffre, 1988; Dulac et al., 1989; Migon et al., 1991, 2001; Duce et al., 1991; Prospero et al. 1996; Nielsen et al., 1996; Zhuang et al., 1999; Spokes et al., 2000; Wesley and Hicks, 2000; Qi et al., 2005; Seinfeld and Pandis, 2006; Zhang et al., 2007). DAD fluxes were calculated using species-specific $V_{\mathrm{d}}$ since the nutrients are known to be associated with different particle fractions. The calculation of $V_{\mathrm{d}}$ is based on a simple parameterization of experimental meteorological measurements to determine atmospheric transport characteristics (Slinn, 1982; Zhang et al., 2001). The magnitudes of $V_{\mathrm{d}}$ estimated were 1.2 and $0.6 \mathrm{~cm} / \mathrm{s}$ for $\mathrm{NO}_{3}^{-}$and $\mathrm{NH}_{4}^{+}$, respectively and $2 \mathrm{~cm} / \mathrm{s}$ for $\mathrm{PO}_{4}^{3-}, 1.2 \mathrm{~cm} / \mathrm{s}$ for TN and $\mathrm{ON}$ and $2 \mathrm{~cm} / \mathrm{s}$ for TP and $\mathrm{OP}$, which are consistent with results reported in the literature (Duce et al., 1991; Prospero et al., 1996; Spokes et al., 2000; Herut et al., 2002, Poor et al., 2006). These estimated $V_{\mathrm{d}}$ could result in an uncertainty of a factor of 2-3 in the calculated fluxes (Duce et al., 1991).

Aerosol $V_{\mathrm{d}}$ varies with particle size from gravitational settling of large particles to impaction and diffusion of small particles (sub-micrometer), and is dependent on climatological and physical conditions in the troposphere. The most important parameters required for estimating $V_{\mathrm{d}}$ through 
empirical calculations are standard deviation of wind speed $\left(\sigma_{\theta}\right)$, molecular diffusion, particle density and particle size. $V_{\mathrm{d}}$ at a particular vertical height was calculated as the inverse of the sum of a number of resistances (Seinfeld and Pandis, 2006) using the following equation:

$V_{\mathrm{d}}=\frac{1}{R_{\mathrm{a}}+R_{\mathrm{b}}+R_{\mathrm{a}} R_{\mathrm{b}} v_{\mathrm{s}}}+v_{\mathrm{s}}$

where $v_{\mathrm{S}}$ is the gravitational settling velocity (which is a function of particle size, density, and viscosity) (Seinfeld and Pandis, 2006), $R_{\mathrm{a}}$ is aerodynamic resistance refers to turbulent transport from the free atmosphere down to the receptor surface $\left(R_{\mathrm{a}}=9 /\left[u \sigma_{\theta}^{2}\right]\right.$, which is a function of wind speed, $u$ and standard deviation of wind speed, $\sigma_{\theta}$, Yamartino, 1984; Turner, 1986) and $R_{\mathrm{b}}$ is quasi-laminar layer resistance (which is a function of particle size, Brownian diffusion, interception and impaction; $R_{\mathrm{b}}$ on water surface is given by van den Berg et al., 2000). Both $R_{\mathrm{a}}$ and $R_{\mathrm{b}}$ are site-specific and are determined to a large extent by atmospheric properties. The formula used for $V_{\mathrm{d}}$ calculation is given in supplementary material (Appendix A). Meteorological parameters such as ambient temperature $(\mathrm{K})$ of $300.8 \pm 0.6$ and $299.7 \pm 0.7$, wind speed $(\mathrm{m} / \mathrm{s})$ of $1.3 \pm 0.49$ and $1.0 \pm 0.32$, and standard deviation of wind direction $\sigma_{\theta}$ (rad) of 0.773 and 0.513 were observed at the sampling location during October 2006 and November 2006, respectively. In SEA atmospheric environment, a majority of aerosols observed in the size range of $0.1-20 \mu \mathrm{m}$ by the optical counter (Clark and Kremer, 2005) was in the fine mode $(<1 \mu \mathrm{m})$. Dominance by fine particles is typical for biomass burning plumes as was observed, for example, in Brazil (Reid and Hobbs, 1998). Both the mass and number concentrations were elevated across the entire size range on hazy days, and the increase in coarse and fine particles could be explained by increased emissions of fine particles during biomass burning through direct or indirect (gas-to-particle conversion) means and the agglomeration of these particles during the long- range transport (See et al., 2006). Based on the size-distributed chemical composition data obtained in Singapore (See et al., 2006 and unpublished data), the coarse $\left(\mathrm{PM}_{2.5-30}\right)$ particles for $\mathrm{NO}_{3}^{-}$and $\mathrm{PO}_{4}^{3-}$ and fine particles $\left(\mathrm{PM}_{0-2.5}\right)$ in the case of $\mathrm{NH}_{4}^{+}$ions were considered in this study. This assumption is also in agreement with other reports in the literature (Wall et al., 1988; Zhuang et al, 1999; Migon et al., 2001; Herut et al., 2002; Reid et al., 2005; Yang et al, 2005; Seinfeld and Pandis, 2006).

\subsubsection{Wet deposition}

WAD involves the removal of atmospheric substances within clouds and below the cloud base mainly by precipitation (Pryor and Barthelmie, 2000). Wet deposition fluxes ( $F_{\text {wet }}$ in $\mathrm{mg} / \mathrm{m}^{2} /$ day) were calculated from the product of the precipitation rate $(\mathrm{P}$ in $\mathrm{m} /$ day) and measured concentrations of nutrient species $\left(C_{\text {rain }}\right.$ in $\left.\mathrm{mg} / \mathrm{l}\right)$ by the following Eq. (3) with unit conversion factor of 1000 :

$F_{\text {wet }}=1000 C_{\text {rain }} P$

Precipitation rate represents the velocity with which pollutants incorporated into precipitation and existing at a given liquid concentrations are deposited. Despite low frequency of rainfall during the 2006 haze episodes, precipitation samples were still collected and analyzed. The cumulative total of rain events during the time interval may be expressed as the sum of all events. The cumulative total precipitation of $48 \mathrm{~mm}, 250.8 \mathrm{~mm}$ and $495.2 \mathrm{~mm}$ was measured during October, November and December 2006, respectively. In this study, the total precipitation by summing the abovementioned three cumulative total precipitation amounts was used for the wet atmospheric flux calculation. Annual precipitation during the year 2006 was $2294.6 \mathrm{~mm}$. The deposition fluxes may show short term variations, rendering the quantification of the annual atmospheric input of nutrients into the sea very difficult.

\section{Results and discussion}

\subsection{Smoke haze episode}

The smoke haze episodes that took place in Singapore during October 2006 were due to the occurrence of hundreds of bush, forest and peat fires across Sumatra and Borneo (National Environment Agency (NEA), Singapore). The prevailing southerly to southwesterly winds transported the smoke haze directly from southern Sumatra towards the Malacca Straits, peninsular Malaysia and Singapore; the smoke haze was also influenced by the prevailing southeasterly winds from Kalimantan to Singapore. The PSI (Pollutant Standards Index) measured by NEA, Singapore and the API (Air Pollution Index) by DOE (Department of Environment), Malaysia are indicators of the prevailing air quality in Singapore and Malaysia, respectively. The air quality categories based on PSI or API and the general health effects associated with different categories of air quality are summarized as follows: PSI or API up to 50:Good; 51-100:Moderate; 101-200:Unhealthy; 201-300:Very Unhealthy; >300:Hazardous. These indices are representative of the levels of particulate air pollution at the respective sites during biomass burning periods. Air quality measurements made by NEA, Singapore at the north, south, east, west and central regions of Singapore formed the basis for the PSI calculation. The TSP measured in this study, PSI (NEA, Singapore) and API (2006 API data from http://en.wikipedia.org/wiki/2006_Southeast_Asian_haze) (Fig. 3a) show the pattern of particulate air pollution in Singapore and Malaysia at George Town $\left(5^{\circ} 25^{\prime} 00^{\prime \prime} \mathrm{N}\right.$ $\left.100^{\circ} 19^{\prime} 00^{\prime \prime} \mathrm{E}\right)$, Johor Bahru $\left(1^{\circ} 29^{\prime} 00^{\prime \prime} \mathrm{N} 103^{\circ} 44^{\prime} 00^{\prime \prime} \mathrm{E}\right)$, Kuala Lumpur $\left(3^{\circ} 8^{\prime} 00^{\prime \prime} \mathrm{N} \quad 101^{\circ} 42^{\prime} 00^{\prime \prime} \mathrm{E}\right)$, Kuantan 

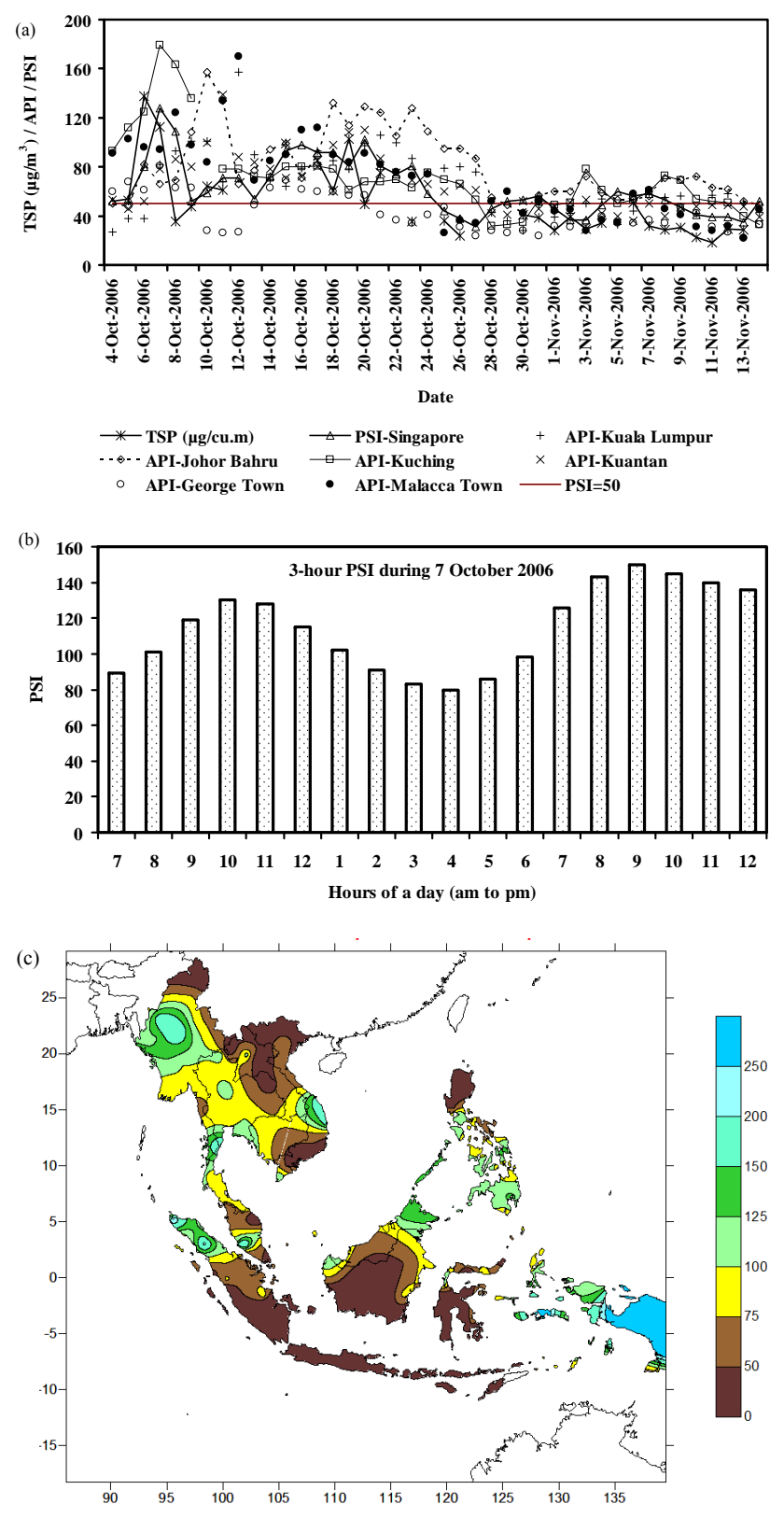

Fig. 3. (a) 3-h PSI on 7 October 2006; (b) Total Suspended Particulates (TSP), Pollutant Standards Index (PSI) (Data from NEA, Singapore) and Air pollution index (API) (Data from DOE, Malaysia) from October 2006 to November 2006; (c) percentage of normal rainfall distribution in SEA during September 2006 (NEA, Singapore). Note: PSI or API $<50$ (Good); 51-100 (Moderate); 101-200 (Unhealthy); 201-300 (Very Unhealthy); >300 (Hazardous).

$\left(3^{\circ} 49^{\prime} 00^{\prime \prime} \mathrm{N} \quad 103^{\circ} 20^{\prime} 00^{\prime \prime} \mathrm{E}\right), \quad$ Kuching $\quad\left(1^{\circ} 33^{\prime} 00^{\prime \prime} \mathrm{N}\right.$ $\left.110^{\circ} 25^{\prime} 00^{\prime \prime} \mathrm{E}\right)$, and Malacca Town $\left(2^{\circ} 11^{\prime} 20^{\prime \prime} \mathrm{N}\right.$ $102^{\circ} 23^{\prime} 4^{\prime \prime}$ E). Figure $3 \mathrm{a}-\mathrm{b}$ shows moderate and unhealthy air quality during regional smoke haze events in SEA in October 2006. Kuching, the capital of the East Malaysian state of Sarawak, is the largest city near Kalimantan (Borneo) where extensive forest fires took place. These islands are situated around Singapore from southeast (SE) to southwest (SW).

The areas of forest fires ranged from several hundred kilometers to about $2000 \mathrm{~km}$ from Singapore. A higher level of TSP was measured in Singapore during the 2006 smoke haze event (maximum TSP $140 \mu \mathrm{g} / \mathrm{m}^{3}$ ) as compared to that measured during the 1997-1998 haze events (maximum TSP $\sim 110 \mu \mathrm{g} / \mathrm{m}^{3}$ ) (Balasubramanian et al., 1999) caused by prolonged forest fires in the nearby provinces of Indonesia. The highest 3-h PSI (150) recorded in Singapore during this haze episode occurred on 7 October 2006 (Fig. 3b); the PSI was calculated based on $\mathrm{PM}_{10}$ (diameter $\left.\leq 10 \mu \mathrm{m}\right)$ concentrations (NEA, Singapore). Figure 3 a shows that the day-today particle concentrations varied substantially in response to spatial and temporal changes of meteorological factors, such as rainfall distribution (Fig. 3c) and wind conditions (Fig. 4a), and of fire activity and intensity (hotspots in Fig. 4). The TSP values measured in Singapore followed a trend which was similar to those in the PSI and API data. The particle concentration exhibited a distinct rise and high fluctuation during October. After mid-November, it decreased and remained at the background level.

The extreme smoke haze episodes that occurred on 7, 15, 17 and 20 October 2006 were selected for DAD estimation during hazy days and the 16 samples collected from 13 November 2006 to 4 January 2007 were selected for non-hazy days. The range of TSP was $99-138 \mu \mathrm{g} / \mathrm{m}^{3}$ and $18-31 \mu \mathrm{g} / \mathrm{m}^{3}$, respectively, during hazy and non-hazy days; the range of PSI was 92-119 and 25-47 during hazy and non-hazy days, respectively. The arithmetic means of TSP and PSI during hazy days were $113 \pm 17 \mu \mathrm{g} / \mathrm{m}^{3}$ and $102 \pm 12$, respectively while those during non-hazy days were $24 \pm 5 \mu \mathrm{g} / \mathrm{m}^{3}$ and $35 \pm 7$, respectively. The air quality reached the unhealthy range (PSI $>100$ ) on 3 days with the highest value being 128 ( $24 \mathrm{~h}$ average PSI) on 7 October 2006.

To investigate the possible sources of particulate air pollution and to assess the recent history and transport pathways of air masses before reaching the monitoring station in SJI, air mass back trajectories were constructed at 3 different heights 40, 100 and $500 \mathrm{~m}$ for a 5-day period using NOAA/ARL Hybrid Single-Particle Lagrangian Integrated Trajectory model (HYSPLIT; Draxler and Rholph, 2003). The 2006 smoke haze event, caused by prolonged, uncontrolled burning from "slash and burn" cultivation in Indonesia, affected several countries in the SEA region and beyond (see Fig. 4a-d), and as far as Saipan (Source: www.saipantribune.com on 5 October 2006). The fires originated mostly in Kalimantan, the Indonesian part of Borneo, and in Sumatra. The 5-day backward trajectories of air masses arriving at the SJI sampling station on three representative days 7, 17 and 20 October 2006 (SWM) and the representative smoke haze extent map in SEA are shown in Fig. 4a-d, respectively. The PSI during these three sampling days was 128, 92 and 102, respectively. During periods of active and intense biomass burning in 

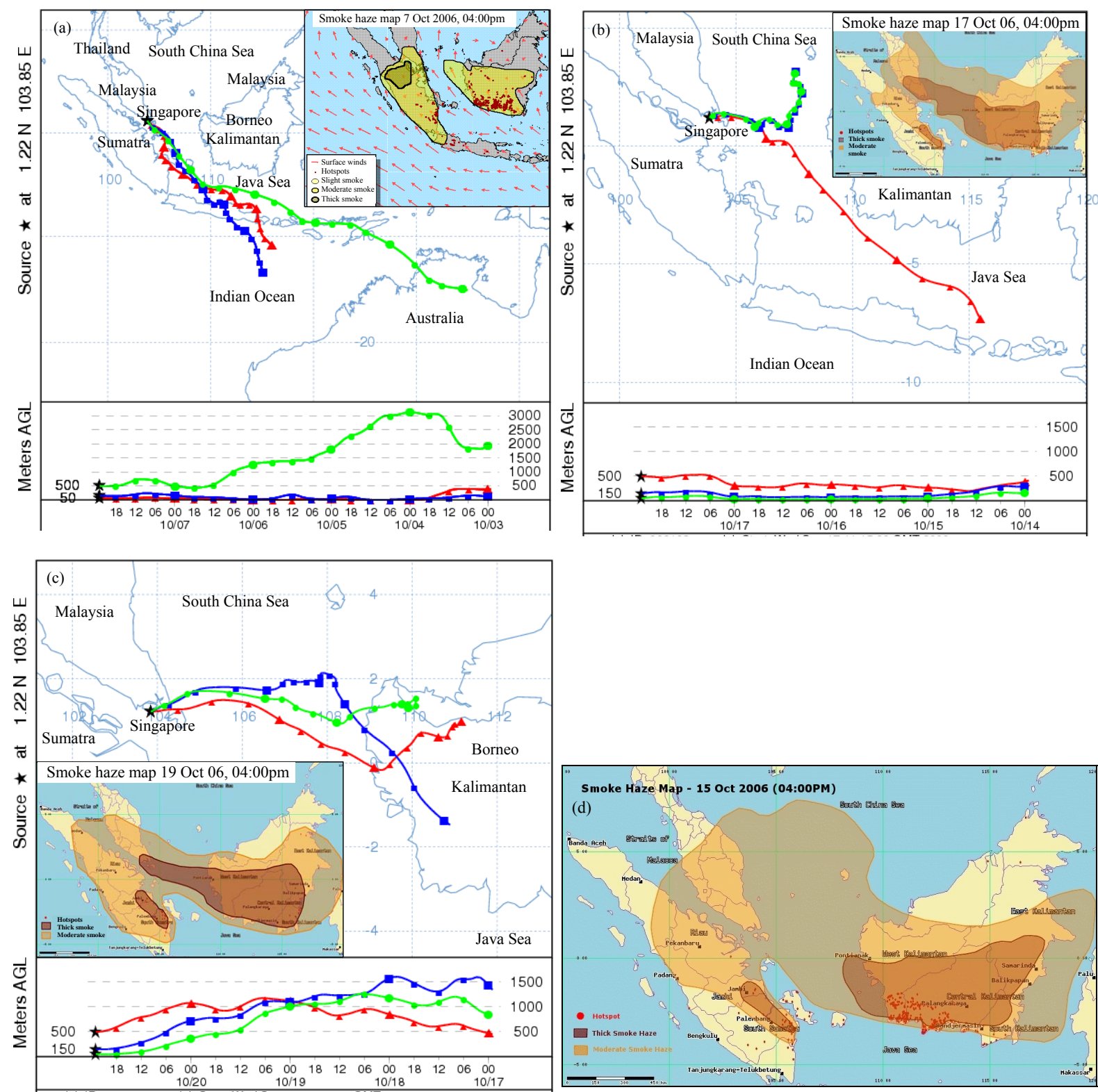

Fig. 4. Back trajectories of air masses for starting altitude of $500 \mathrm{~m}, 100 \mathrm{~m}$, and $40 \mathrm{~m}$ above ground level (a.g.1.) calculated from NOAA HYSPLIT model for the sampling site in SJI and the extent of the smoke haze in SEA due to forest fires in Indonesia (courtesy: NEA, Singapore) (a) 7 October 2006; (b) 17 October 2006; (c) 20 October 2006 and (d) the representative regional smoke haze map (NEA, Singapore).

Sumatra and Borneo, spells of moderate to dense smoke haze could be expected in the vicinity of the larger fire/hotspot clusters in the affected areas (see Fig. 4). The HYSPLIT model calculation results showed that the air mass was transported from different source areas to Singapore across the Indian Ocean at lower altitudes.

During the first haze event (Fig. 4a), one air mass back trajectory traveled from Australia at a high altitude of $2000 \mathrm{~m}$ while other two air mass back trajectories travelled from the Indian Ocean at a low attitude $(<500 \mathrm{~m})$ through Sumatra, Java Sea and other areas impacted by forest and peat fires. The PM concentration at SJI was largely dependent on the direction of the prevailing winds (with southeasterly to southwesterly winds favoring the transport of haze towards Singapore), the fire activity (its location and intensity) and El Niño/Southern Oscillation (ENSO) (its effect on rainfall, atmospheric stability and convective activity). The monsoon transition shifted the wind pattern towards Peninsular Malaysia. It created convergence zones near Singapore and induced subsidence in the area as well (Koe et al., 2001). The local effects of land and sea breezes also contributed to the enhancement of PM concentration in Singapore, particularly 
during the transition period (Koe et al., 2001). During the other two haze events (Fig. 4b-c), the air masses mostly originated from Kalimantan and the surrounding areas. The biomass burning-impacted air masses contained elevated levels of airborne particulate matter compared to those originated from other sources of air pollution (Koe et al., 2001; Abas et al., 2004; See et al., 2006).

\subsection{Atmospheric nutrient deposition}

\subsubsection{Dry deposition}

The concentration of soluble inorganic and organic nutrients (N and $\mathrm{P}$ species) obtained from TSP samples on selected days with hazy (October 2006) and non-hazy (November 2006-January 2007) conditions in Singapore are shown in Fig. 5a. It is clearly seen that there is similarity in the patterns of $\mathrm{N}$ and $\mathrm{P}$ species and the occurrences of very high concentrations of nutrients during hazy days when compared to non-hazy days. Higher fluctuations in concentration of $\mathrm{N}$ and $\mathrm{P}$ species were observed during hazy days than those during non-hazy days with the exception of $\mathrm{NH}_{4}^{+}$and $\mathrm{PO}_{4}^{3-}$. The dry deposition of $\mathrm{NO}_{2}^{-}+\mathrm{NO}_{3}^{-}$was generally greater than that of $\mathrm{NH}_{4}^{+}$. However, $\mathrm{NH}_{4}^{+}$deposited onto water bodies is susceptible to be oxidized to $\mathrm{NO}_{3}^{-}$under favorable weather conditions. ON deposition was generally greater than that of inorganic $\mathrm{N}\left(\mathrm{NH}_{4}^{+}+\mathrm{NO}_{3}^{-}+\mathrm{NO}_{2}^{-}\right)$deposition. OP deposition was generally much greater than that of $\mathrm{PO}_{4}^{3-}$ during hazy days. As the tropical biomass burning is an important source of atmospheric N and P (Crutzen and Andreae, 1990; Mahowald et al., 2005), the increased deposition of $\mathrm{N}$ and $\mathrm{P}$ species is conceivable. The high proportion of $\mathrm{OP} \mathrm{ob}-$ served in this study is consistent with the findings reported in the literature that OP could account for about $30-80 \%$ of TP concentration (Markaki et al., 2003; Mahowald et al., 2008; Vicars et al., 2010).

DAD fluxes of $\mathrm{N}$ and $\mathrm{P}$ species were calculated from the field observations of DAD nutrients concentration (Fig. 5a) using the Eq. (1) in Sect. 2.3.1. Figure 5b shows the DAD fluxes of $\mathrm{N}$ and $\mathrm{P}$ species during hazy and non-hazy days. The DAD flux was much higher for TN and TP during hazy days as compared to non-hazy days. The flux decreased in the following order: $\mathrm{ON}>\mathrm{NO}_{2}^{-}+\mathrm{NO}_{3}^{-}>\mathrm{NH}_{4}^{+}$for $\mathrm{N}$ species and $\mathrm{OP}>\mathrm{PO}_{4}^{3-}$ for $\mathrm{P}$ species during both hazy and non-hazy days. For both $\mathrm{N}$ and $\mathrm{P}$ species, mean total deposition rates were several times greater than the deposition rates of inorganic species, indicating that much of the dry deposition was in soluble organic form. It is known that dissolved ON (DON) is the most abundant organic $\mathrm{N}$ form and is potentially mineralized in ecosystems. Also, DON such as urea and amino acids can be directly taken up by some plants (Cornell et al., 2003). Consequently, the DON deposition rate must be one of the important factors controlling the $\mathrm{N}$ in ecosystems.

\subsubsection{Wet deposition}

The concentrations of nutrients ( $\mathrm{N}$ and $\mathrm{P}$ species) in rainwater during hazy and non-hazy days are shown in Fig. 6a. Rainwater samples ( 3 rain events) were selected based on the PSI from 15 to 21 October 2006 for hazy days. 3 rain events were selected from 11 November 2006 to 23 December 2006 for non-hazy days. The range of PSI during hazy and non-hazy days was $81-93$ and 35-39, respectively. The range of wet deposition concentrations of $\mathrm{N}$ species during hazy days was in the order of $11.76-$ $20.36 \mathrm{mg} / \mathrm{l}$ for TN, $3.21-10.50 \mathrm{mg} / \mathrm{l}$ for ON, $7.78-9.48 \mathrm{mg} / \mathrm{l}$ for $\mathrm{NO}_{3}^{-}+\mathrm{NO}_{2}^{-}$, and $0.77-1.19 \mathrm{mg} / \mathrm{l}$ for $\mathrm{NH}_{4}^{+}$. On the other hand, the range of WAD concentrations of $\mathrm{N}$ species during non-hazy days was in the order of $2.38-4.79 \mathrm{mg} / \mathrm{l}$ for TN, $1.30-2.52 \mathrm{mg} / \mathrm{l}$ for $\mathrm{ON}, 1.03-2.24 \mathrm{mg} / \mathrm{l}$ for $\mathrm{NO}_{3}^{-}+$ $\mathrm{NO}_{2}^{-}$, and $0.03-0.39 \mathrm{mg} / \mathrm{l}$ for $\mathrm{NH}_{4}^{+}$. On an event basis, the concentration of macro-nutrients in rainwater was highly variable. The mean concentrations of $\mathrm{P}$ species from wet deposition were $0.91 \pm 0.09 \mathrm{mg} / \mathrm{l}$ for TP, $0.65 \pm 0.29 \mathrm{mg} / \mathrm{l}$ for $\mathrm{OP}$ and $0.26 \pm 0.20 \mathrm{mg} / \mathrm{l}$ for $\mathrm{PO}_{4}^{3-}$ for hazy days and $0.18 \pm 0.08 \mathrm{mg} / \mathrm{l}$ for $\mathrm{TP}, 0.15 \pm 0.09 \mathrm{mg} / \mathrm{l}$ for $\mathrm{OP}$ and $0.03 \pm 0.01 \mathrm{mg} / \mathrm{l}$ for $\mathrm{PO}_{4}^{3-}$ for non-hazy days. The reported concentrations of $\mathrm{NH}_{4}^{+}$and $\mathrm{NO}_{3}^{-}$in rainwater were $0.31 \mathrm{mg} / \mathrm{l}$ and $1.04 \mathrm{mg} / \mathrm{l}$ during 1997 to 1998 in Singapore (Balasubramanian et al., 2001), and $0.25 \mathrm{mg} / \mathrm{l}$ and $1.23 \mathrm{mg} / \mathrm{l}$, respectively during 1996 to 1997 in Malaysia (Ayers et al., 2002). A sporadic increase in the concentration levels of nutrients such as $\mathrm{NH}_{4}^{+}, \mathrm{NO}_{3}^{-}$and $\mathrm{PO}_{4}^{3-}$ resulting from biomass burning has been reported by Lobert et al., 1990; Crutzen and Andreae, 1990; Mayewski et al., 1993, 1997; Kondo et al., 2004; Mahowald et al., 2005, 2008. The contribution of WAD of nutrients followed the order $\mathrm{TN}>\mathrm{NO}_{2}^{-}+\mathrm{NO}_{3}^{-}>\mathrm{ON}>\mathrm{NH}_{4}^{+}$for $\mathrm{N}$ species and $\mathrm{TP}>\mathrm{OP}>\mathrm{PO}_{4}^{3-}$ for $\mathrm{P}$ species. The mean concentrations of atmospheric aerosol and rainwater were comparable to the fluxes from land-based sources such as wastewater treatment plants $(\mathrm{TN}=2.13 \mathrm{mg} / \mathrm{l}$ and $\mathrm{TP}=0.17 \mathrm{mg} / \mathrm{l})$ and rivers $\left(\mathrm{NH}_{4}^{+}=0.16 \mathrm{mg} / \mathrm{l}, \quad \mathrm{NO}_{2}^{-}+\mathrm{NO}_{3}^{-}=0.34 \mathrm{mg} / \mathrm{l}\right.$ and $\left.\mathrm{PO}_{4}^{3-}=0.14 \mathrm{mg} / \mathrm{l}\right)(\mathrm{DHI}, 2004)$ in the Singapore coastal waters.

The magnitude of wet deposition fluxes depends on precipitation rate. In this study, the precipitation of $794 \mathrm{~mm}$, a cumulative rainfall amount of rain events during the study period of October 2006 to December 2006, was used for estimation of the wet deposition flux. Figure $6 \mathrm{~b}$ shows the wet atmospheric deposition fluxes of $\mathrm{N}$ and $\mathrm{P}$ species during hazy and non-hazy days in Singapore. The estimated mean wet deposition fluxes of water soluble $\mathrm{NO}_{2}^{-}+\mathrm{NO}_{3}^{-} \mathrm{N}$ and $\mathrm{PO}_{4}^{3-}$ into the Singapore coastal waters were $75.57 \pm 7.31 \mathrm{mg} / \mathrm{m}^{2} /$ day and $2.25 \pm 1.75 \mathrm{mg} / \mathrm{m}^{2} /$ day during hazy days, and $13.33 \pm 5.39 \mathrm{mg} / \mathrm{m}^{2} /$ day and $0.29 \pm 0.09 \mathrm{mg} / \mathrm{m}^{2} /$ day during non-hazy days, respectively. The estimated mean wet deposition fluxes $\left(\mathrm{mg} / \mathrm{m}^{2} /\right.$ day $)$ of $\mathrm{NH}_{4}^{+}$were $8.11 \pm 1.94$ and $1.33 \pm 1.79$ during hazy and 
(a)
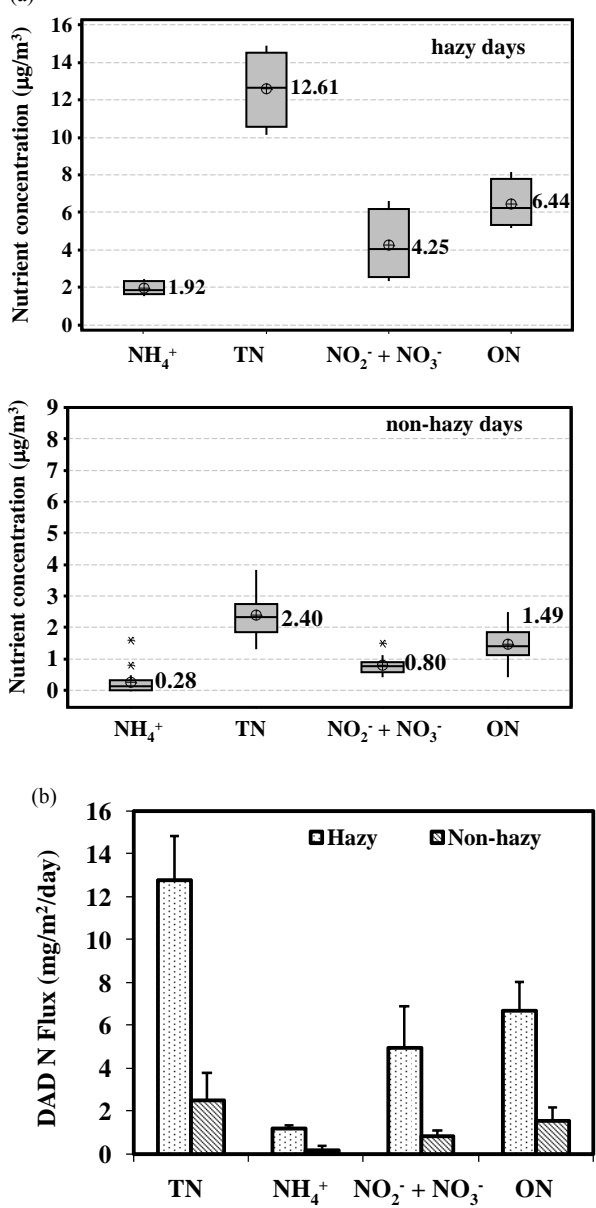
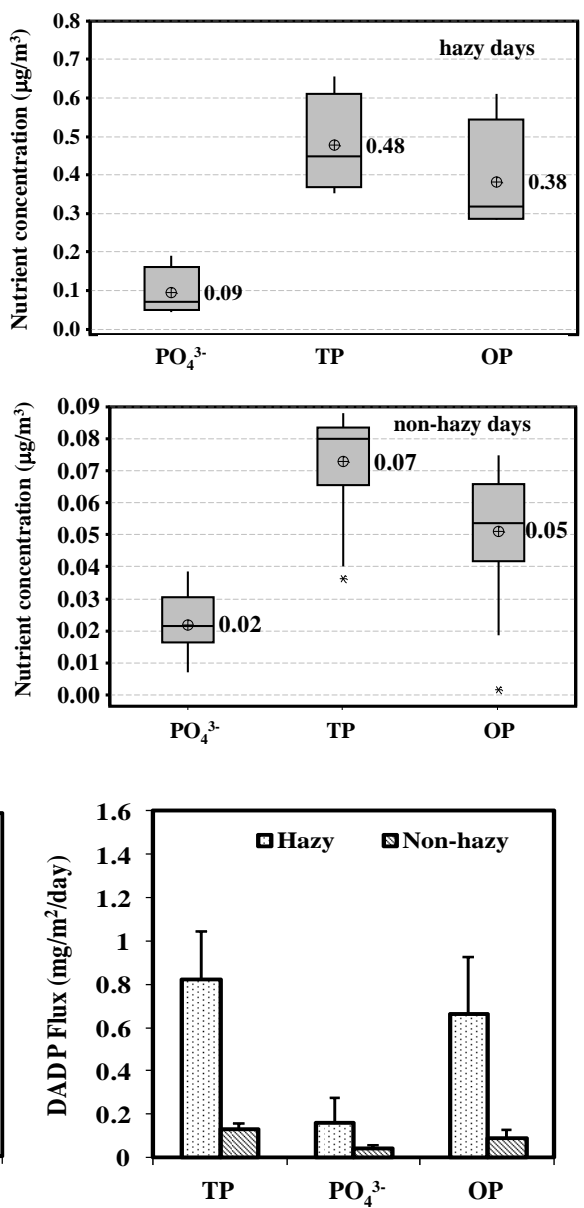

Fig. 5. (a) Box plot showing mean concentration of nutrients ( $\mathrm{N}$ and $\mathrm{P}$ species) $\left(\mu \mathrm{g} / \mathrm{m}^{3}\right)$ in aerosol samples on selected days with hazy (October 2006) and non-hazy (November 2006-January 2007) conditions (crossed circle shows mean); (b) fluxes of nutrients (N and P species) in DAD during hazy and non-hazy days. Note: in (a), the bottom and the top edges of each box are located at the sample 25 and 75 percentiles, the height of each box shows the interquartile range for each species which is an indicator of the variability of the values; the central horizontal line is drawn at the sample median.

non-hazy days, respectively. Nominal annual average wet deposition fluxes $\left(\mathrm{g} / \mathrm{m}^{2} /\right.$ year $)$ of $\mathrm{NH}_{4}^{+}$and $\mathrm{NO}_{3}^{-}$reported in SEA were 0.718 and 3.607 in Malaysia during 1993-1998 (Ayers et al., 1999, 2002), 1.383 and 1.74 in Indonesia during 1992 and 1996 (Gillett et al., 2000) and 0.079 and 0.308 in Australia (Ayers and Yeung, 1996). The estimated mean wet deposition fluxes of TN and TP were higher during hazy days by a factor of 4 as compared to those during non-hazy days. Inorganic $\mathrm{N}$ species accounted for a higher proportion of TN. In contrast, OP made a higher contribution to TP than IP. The estimated atmospheric $\mathrm{N}$ fluxes during non-hazy days in this study are comparable to those reported earlier for Singapore (Karthikeyan et al., 2009a). The WAD fluxes (about 3 times) were higher when annual precipitation rate $(2136 \mathrm{~mm})$ was used for flux estimation instead of $794 \mathrm{~mm}$ as obtained during the study period. This ultimate WAD flux might be applied as a constant uniform load deposited from the atmosphere over the coastal water in these region for a eutrophication modelling study to understand their impact on water quality (Sundarambal et al., 2010).

Baeyens et al. (1990) described a method which allows estimation of the annual wet deposition flux of dissolved ions without measuring all rain events. When one rain event was sampled in several steps (sequential sampling), a nice, smooth dilution profile was obtained (Xianren and Baeyens, 1990) and the concentration decreased gradually with the volume of rainfall. Moy et al. (1994) found that slow air circulation coincided with a high concentration of pollutant gases in the atmosphere. If substantial precipitation occurred then, more removal of pollutants from the atmosphere would occur, as evidenced by their high concentrations in the rain water measurement. As reported by Migon et al. (1991), the number of rain events has a greater influence on flux than the intensity of the rain. It was observed in our study that, after long dry periods (typically several days), nutrient concentrations in rainwater were systematically higher than 

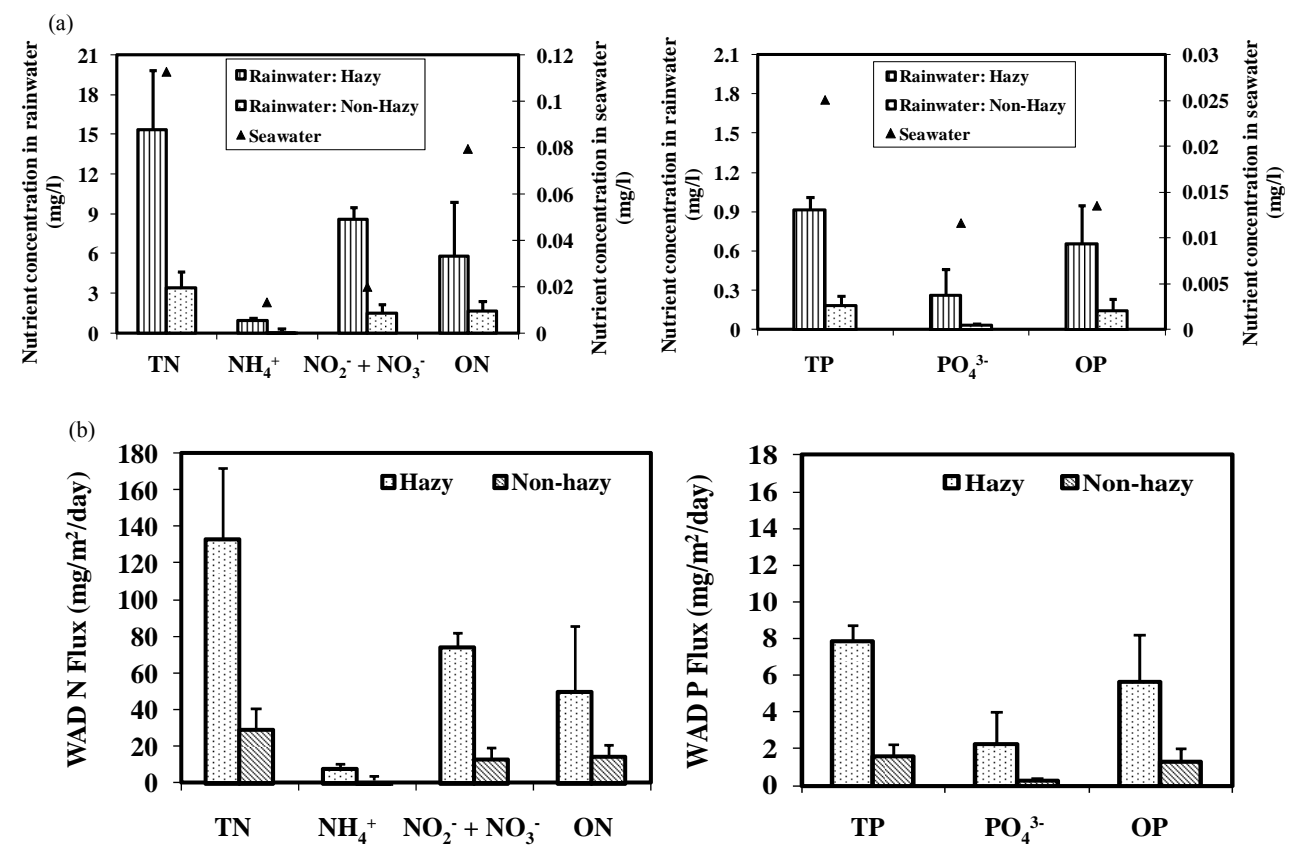

Fig. 6. (a) Concentration of nutrients ( $\mathrm{N}$ and $\mathrm{P}$ species) in rainwater during hazy and non-hazy days and seawater; (b) fluxes of nutrients ( $\mathrm{N}$ and $\mathrm{P}$ species) in WAD during hazy and non-hazy days.

monthly mean concentrations, regardless the intensity of the rain event.

Concentrations of most ions in rainwater were higher during periods of intense biomass fires and the resultant haze than during periods when there were no significant forest fires. This conclusion derived from a short measurement period is consistent with the findings from earlier studies (Balasubramanian et al., 1999; See et al., 2006), according to which most of the chemical species (including inorganic ions) were higher on hazy days as compared to clear days. These air pollution episodes affected the local air quality in Singapore, and contributed to the increase in TN content in precipitation samples (Karthikeyan et al., 2009a). The WAD flux is higher than the DAD flux. The total budget shows that the biologically available $\mathrm{N}$ load to the surface water is significantly more than 10 times the biologically available $\mathrm{P}$ load to the surface water (Figs. 5 and 6). A similar pattern of nutrient concentrations was observed in rainwater and seawater (Fig. 6a). The seawater concentrations (which are used as model baseline values) in Fig. 6a were obtained by the statistical analysis of the data measured every month at 3 different depths (surface, mid depth and bottom) at field monitoring stations in the Singapore seawaters (as part of the routine water quality monitoring program by the Tropical Marine Science Institute (TMSI)) (Tkalich and Sundarambal, 2003; Gin et al., 2006). There was a significant concentration variation in coastal areas of the Singapore Strait and the Johor Strait in both space and time (Gin et al., 2000, 2006).
The high ratio of nutrients between hazy and non-hazy days (Fig. 7) in aerosol and rainwater clearly indicates that atmospheric deposition during smoke haze episodes is a significant source of nutrients to the coastal waters of Singapore and SEA. The ranking of $\mathrm{N}$ species from DAD and WAD in terms of ratios between those observed during hazy and nonhazy days was $\mathrm{NH}_{4}^{+}>\mathrm{NO}_{3}^{+}+\mathrm{NO}_{2}^{+}>\mathrm{TN}>\mathrm{ON}$. The ranking of $\mathrm{P}$ species from $\mathrm{DAD}$ and $\mathrm{WAD}$ was $\mathrm{OP}>\mathrm{TP}>\mathrm{PO}_{4}^{3-}$ and $\mathrm{PO}_{4}^{3-}>\mathrm{TP}>\mathrm{OP}$, respectively (Fig. 7). The purpose of the rankings of nutrients resulting from atmospheric deposition during hazy and non-hazy days is to understand the contribution of each species to changes in the water quality and thus to coastal water eutrophication. Since WAD and DAD contribute different forms of nutrients at different rates, the availability, stoichiometry, and nutrient loads from atmospheric sources would vary greatly with the rate and timing of precipitation. The haze events that have plagued SEA are likely to affect atmospheric fluxes of nutrients and other pollutants into aquatic systems.

Atmospheric deposition in Singapore and surrounding countries appears to provide considerable fluxes of nutrients of environmental concern, and it may thus play an important role in the coastal eutrophication. The eutrophication model "NEUTRO" (Tkalich and Sundarambal, 2003) was used for the simulation of spatial and temporal nutrient dynamics, and to predict the water quality trends in Singapore coastal waters. The research focus of this paper is only to quantify the atmospheric deposition of nutrients ( $\mathrm{N}$ and $\mathrm{P}$ species) while the companion article (Sundarambal et al., 2010) deals with 


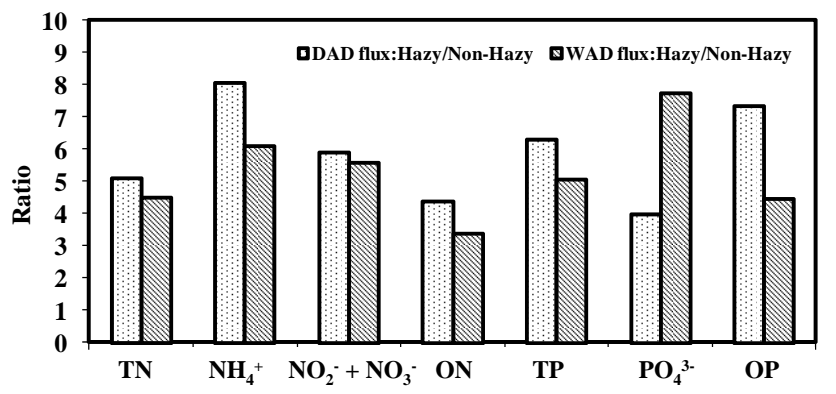

Fig. 7. Ratio of hazy to non-hazy days fluxes of $\mathrm{N}$ and $\mathrm{P}$ species in DAD and WAD during 2006 haze episodes, SEA.

the estimation of the relative contribution of atmospheric nutrient deposition to coastal water eutrophication.

\section{Implications and outlook}

In this study, different forms of water soluble nutrients ( $\mathrm{N}$ and $\mathrm{P}$ species only) from dry atmospheric deposition (aerosol particulates) and wet atmospheric deposition (rainwater) were quantified for the first time at a coastal location in SEA using established methods. Our findings from a short-term study with a limited number of samples indicate that atmospheric deposition can be a significant source of nutrients to aquatic ecosystems. The concentrations of nutrients ( $\mathrm{N}$ and $\mathrm{P}$ species) in aerosol and rainwater were higher during hazy days as compared to those during non-hazy days. It was observed that the average concentrations of nutrients increased approximately between a factor of 3 and 8 on hazy days when compared with non-hazy days. The high ratio of nutrients between hazy and non-hazy days indicates that smoke haze episodes provided a significant source of nutrients to the coastal water in Singapore and SEA. The quantified nutrient fluxes from atmospheric deposition provided a baseline to study the possible ecosystem responses to atmospheric nutrient inputs to the water surface. These quantitative and qualitative aspects of atmospheric nutrient sources may promote biotic changes now apparent in estuarine and coastal waters with cascading impacts on water quality, and trophic and biogeochemical alterations (i.e., algal blooms, hypoxia, food web, and fisheries habitat disruption). Air mass back trajectories showed that large-scale forest and peat fires in Sumatra and Kalimantan were a significant source of atmospheric nutrients to the aquatic environment in the SEA region. In view of recurring biomass burning episodes in this region, there is a need to establish a network of research stations for simultaneous air and water quality monitoring in order to address the impacts of atmospheric deposition of nutrients onto coastal water in SEA. The information presented in this paper advances scientific knowledge in issues related to atmospheric deposition of pollutants, particularly nutrients, to coastal waters of SEA.
In conclusion, we find that biomass burning in and around SEA acts as a highly significant source of nutrients (both inorganic and organic $\mathrm{N}$ and $\mathrm{P}$ species) through atmospheric deposition to the regional surface waters such as estuarine, coastal waters, and the open ocean during haze episodes. However, a more comprehensive study over an extended period of time is needed to confirm this conclusion. The quantified atmospheric deposition fluxes of nutrients provide a baseline to study the possible ecosystem responses to atmospheric nutrient inputs into the water surface. In order to assess the effects of atmospheric inputs on coastal waters and to enhance our understanding of the interactions of physical, chemical, and biological processes controlling aquatic ecosystems, a eutrophication modeling study is needed. Results obtained from the modeling work carried out in conjunction with field observations are presented in a companion article (Sundarambal et al., 2010).

\section{Supplementary material related to this article is available online at: http://www.atmos-chem-phys.net/10/11323/2010/ acp-10-11323-2010-supplement.pdf.}

Acknowledgements. This research is a part of the main author's $\mathrm{PhD}$ research. We would like to thank Karthikeyan Sathrugnan for technical guidance in laboratory analysis, the Division of Environmental Science and Engineering for providing laboratory facilities, and Tropical Marine Science Institute, National University of Singapore for the financial and technical support. One of the authors, Rajasekhar Balasubramanian, gratefully acknowledges the support from the Singapore-Delft Water Alliance (SDWA). The research presented in this work was carried out as part of the SDWA's research programme (R-264-001-013-272). We are grateful to Serena Teo, Tan Koh Siang, Er. Lim Chin Sing and their group for sample collections at Tropical Marine Science Institute in St. John's Island (SJI), Singapore. We thank the three anonymous reviewers for their constructive comments on the manuscript.

Edited by: A. Chen

\section{References}

Abas, M. R., Oros, D. R., and Simoneit, B.: Biomass burning as the main source of organic aerosol particulate matter in Malaysia during haze episodes, Chemosphere, 55, 1089-1095, 2004.

Ayers, G. P. and Yeung, K. K.: Acid deposition in Hong Kong, Atmos. Environ., 30(10/11), 1581-1587, 1996.

Ayers, G. P., Peng, L.C., Fook, L. S., Kong, C.W.; Gillett, R. W., and Manins, P. C.: Atmospheric concentrations and deposition of oxidised sulfur and nitrogen species at Petaling Jaya, Malaysia 1993-1998, Tellus, 52, 60-73, 1999.

Ayers, G. P. Peng, L. C., Gillett, R. W., and Fook, L. Z.: Rainwater composition and acidity at five sites in Malaysia, in 1996, Water Air Soil Poll., 133, 15-30, 2002. 
Ayars, J. and Gao, Y.: Atmospheric nitrogen deposition to the Mullica River-Great Bay Estuary, Marine Environ. Res., 64, 590$600,2007$.

Baeyens, W., Dehairs, F., and Dedeurwaerder, H. Wet and dry deposition fluxes above the North Sea, Atmos. Environ., 24A(7), 1693-1703, 1990.

Balasubramanian, R., Victor, T., and Begum, R.: Impact of biomassburning on rainwater acidity and composition in Singapore, J. Geophys. Res., 104, 26881-26890, 1999.

Balasubramanian, R., Victor, T., and Chun, N.: Chemical and statistical analysis of precipitation in Singapore, Water Air Soil Poll., 130, 451-456, 2001.

Balasubramanian, R., Qian, W. B., Decesari, S., Facchini, M. C., and Fuzzi, S.: Comprehensive characterization of PM2.5 aerosols in Singapore, J. Geophys. Res., 108(D16), 4523, doi:10.1029/2002JD002517, 2003.

Balasubramanian, R. and Qian, W. B.: Characterization and source identification of airborne trace metals in Singapore, J. Environ. Monit., 8, 813-818, 2004.

Bartoli, G., Migon, C., and Losno, R.: Atmospheric input of dissolved inorganic phosphorus and silicon to the coastal northwestern Mediterranean Sea: Fluxes, variability and possible impact on phytoplankton dynamics, Deep-Sea Res. Pt. I, 52, 2005-2016, 2005.

Caruso, E., Braga Marcazzan, G. M. and Redaelli, P.: PIXE investigation of element concentration and particle size distribution in Milan atmospheric aerosol, Nucl. Instrum. and Methods, 181, 425-429, 1981.

Chen, Y., Mills, S., Street, J., Golan, D. Post, A., Jacobson, M., and Paytan, A.: Estimates of atmospheric dry deposition and associated input of nutrients to Gulf of Aqaba seawater, J. Geophys. Res., 112, D04309, doi:10.1029/2006JD007858, 2007.

Clark, H. and Kremer, J. N.: Estimating direct and episodic atmospheric nitrogen deposition to a coastal waterbody, Marine Environ. Res., 59(4), 349-366, 2005.

Cornell, S. E., Jickells, T. D., Cape, J. N., Rowland, A. P., and Duce, R. A.: Organic nitrogen deposition on land and coastal environments: a review of methods and data, Atmos. Environ., 37, 2173-2191, 2003.

Crutzen, P. J. and Andreae, M. O.: Biomass burning in the tropics: impact on atmospheric chemistry and biogeochemical cycles, Science, 250, 1669-1678, 1990.

DHI: Detailed studies on Tuas View extension and Pulau Tekong land reclamation. Final Report, Volume VIII Water quality impact assessment, Danish Hydraulic Institute, 2004.

DOE: Department Of Environment, Ministry of Natural Resources and Environment, Malaysia, URL: http://www.doe.gov.my/, last access: October 2006.

Draxler, R. R. and Rholph, G. D.: HYbrid Single-Particle Lagrangian Integrated Trajectory (HYSPLIT) Model access via NOAA ARL READY, Website, NOAA Air Resources Laboratory, Silver Spring, MD, 2003.

Duarte, C. M., Dachs, J., Llabrés, M., Alonso-Laita, P., Gasol, J. M., Tovar-Sánchez, A., Sañudo-Wilhemy, S., and Agustí, S.: Aerosol inputs enhance new production in the subtropical northeast Atlantic, J. Geophys. Res., 111, G04006, doi:10.1029/2005JG000140, 2006.

Duce, R.: The impact of atmospheric nitrogen, phosphorus, and iron species on marine biological productivity, in: The Role of
Air-Sea Exchange in Geochemical Cycling, edited by: BuatMenard, P., D. Reidel, Norwell, MA, 497-529, 1986.

Duce, R. A., Liss, P. S., Merrill, J. T., Atlas, E. L., Buat-Menard, P., Hicks, B. B., Miller, J. M., Prospero, J. M., Arimoto, R., Church, T. M., Ellis, W., Galloway, J. N., Hansen, L., Jickells, T. D., Knap, A. H., Reinhardt, K. H., Schneider, B., Soudine, A., Tokos, J. J., Tsunogai, S., Wollast, R., and Zhou, M.: The atmospheric input of trace species to the world ocean, Global Biogeochem. Cy., 5, 193-259, 1991.

Duce, R. A., LaRoche, J., Altieri, K., Arrigo, K. R., Baker, A. R., Capone, D. G., Cornell, S., Dentener, F., Galloway, J., Ganeshram, R. S., Geider, R. J., Jickells, T., Kuypers, M. M., Langlois, R., Liss, P. S., Liu, S. M., Middelburg, J. J., Moore, C. M., Nickovic, S., Oschlies, A., Pedersen, T., Prospero, J., Schlitzer, R., Seitzinger, S., Sorensen, L. L., Uematsu, M., Ulloa, O., Voss, M., Ward, B., and Zamora, L.: Impacts of Atmospheric Anthropogenic Nitrogen on the Open Ocean, Science, 320(5878), 893-897, 2008.

Dulac, F., Buat-Ménard, P., Ezat, U., and Bergametti, G.: Atmospheric input of trace metals to the western Mediterranean Sea: uncertainties in modelling dry deposition from cascade impactor data, Tellus, 41B, 362-378, 1989.

Galloway, J. N., Levy II, H., and Kasibhatla, P. S.: Year 2020: Consequences of population growth and development on deposition of oxidized nitrogen, Ambio, 23, 120-123, 1994.

Gillett, R. W., Ayers, G. P., Selleck, P. W., Tuti, M. H. W., and Harjanto, H.: Concentrations of nitrogen and sulfur species in gas and rainwater from several sites in Indonesia, Water Air Soil Poll., 120, 205-215, 2000.

Gin, K. Y. H., Lin, X., and Zhang, S.: Dynamics and size structure of phytoplankton in the coastal waters of Singapore, J. Plankton Res., 22, 1465-1484, 2000.

Gin, K. Y. H., Holmes, M. J., Zhang, S., and Lin, X.: Phytoplankton structure in the tropical port waters of Singapore, in: The Environment in Asia Pacific Harbours, Chapter 21, edited by: Wolanski, E., Springer, Netherlands, 347-375, 2006.

Hasager, C. B., Carstensen, J., Ellermann, T., Gustafson, B. G., Hertel, O., Johnsson, M., Markager, S., and Ambelas Skjøth, C.: On extreme atmospheric and marine nitrogen fluxes and chlorophylla levels in the Kattegat Strait, Atmos. Chem. Phys., 3, 797-812, doi:10.5194/acp-3-797-2003, 2003.

Herut, B., Krom, M. D., Pan, G., and Mortimer, R.: Atmospheric input of nitrogen and phosphorus to the Southeast Mediterranean: sources, fluxes, and possible impact, Limnol. Oceanogr., 44, 1683-1692, 1999.

Herut, B., Collier, R., and Krom, M.: The role of dust in supplying nitrogen and phosphorus to the Southeast Mediterranean, Limnol. Oceanogr., 47, 870-878, 2002.

Joffre, S. M.: Modelling the dry deposition velocity of highly soluble gases to the sea surface, Atmos. Environ., 22(6), 1137-1146, 1988.

Karthikeyan, S. and Balasubramanian, R.: Evaluation of microwave assisted extraction for determination of water soluble inorganic species in airborne particulate matter, Anal. Bioanal. Chem., 381, 1604-1608, 2005a.

Karthikeyan, S. and Balasubramanian, R.: Rapid extraction for water soluble organic compounds in airborne particulate matter, Anal. Sci., 21, 1505-1508, 2005b.

Karthikeyan, S. and Balasubramanian, R.: Determination of water 
soluble inorganic and organic species, Michrochem. J., 82, 4955, 2006.

Karthikeyan, S., See, S., and Balasubramanian, R.: Simultaneous determination of inorganic anions and selected organic acids in airborne particulate patter by Ion Chromatography, Anal. Lett., 40, 1-12, 2007.

Karthikeyan, S., He, J., Sundarambal, P., Balasubramanian, R., and Burger, D. Determination of total nitrogen in atmospheric wet and dry deposition samples, Talanta, 77(3), 979-984, 2009a.

Karthikeyan, S., Balasubramanian, R., and He, J.: Inter-laboratory study to improve the quality of the analysis of nutrients in rainwater chemistry, Atmos. Environ., 43(21), 3424-3430, 2009b.

Koe, L. C. C., Arellano Jr., A. F., and McGregor, J. L.: Investigating the haze transport from 1997 biomass burning in Southeast Asia: its impact upon Singapore, Atmos. Environ., 35, 2723 2734, 2001.

Kondo, Y., Morino, Y., Takegawa, N., Koike, M., Kita, K., Miyazaki, Y., Sachse, G. W., Vay, S. A., Avery, M. A., Flocke, F., Weinheimer, A. J., Eisele, F. L., Zondlo, M. A., Weber, R. J., Singh, H. B., Chen, G., Crawford, J., Blake, D. R., Fuelberg, H. E., Clarke, A. D., Talbot, R. W., Sandholm, S. T., Browell, E. V., Streets, D. G., and Liley, B.: Impacts of biomass burning in Southeast Asia on ozone and reactive nitrogen over the Western Pacific in spring, J. Geophys. Res., 109, D15S12, doi:10.1029/2003JD004203, 2004.

Krom, M. D., Kress, N., Brenner, S., and Gordon, L. I.: Phosphorus limitation of primary productivity in the eastern Mediterranean Sea, Limnol. Oceanogr., 36, 424-432, 1991.

Lobert, J. M., Scharffe, D. H., Hao, W. M., and Crutzen, P. J.: Importance of biomass burning in the atmospheric budgets of nitrogen-containing gases, Nature, 346, 552-554,1990.

Mahowald, N. M., Artaxo, P., Baker, A. R., Jickells, T. D., Okin, G. S., Randerson, J. T., and Townsend, A. R.: Impacts of biomass burning emissions and land use change on Amazonian atmospheric phosphorus cycling and deposition, Global Biogeochem. Cy., 19, GB4030, doi:10.1029/2005GB002541, 2005.

Mahowald, N., Jickells, T. D., Baker, A. R., Artaxo, P., BenitezNelson, C. R., Bergametti, G., Bond, T. C., Chen, Y., Cohen, D. D., Herut, B., Kubilay, N., Losno, R., Maenhaut, C. L. W., McGee, K. A., Okin, G. S., Siefert, R. L., and Tsukuda, S.: Global distribution of atmospheric phosphorus sources, concentrations and deposition rates and anthropogenic impacts, Global Biogeochem. Cy., 22, GB4026, doi:10.1029/2008GB003240, 2008.

Markaki, Z., Oikonomou, K., Kocak, M., Kouvarakis, G., Chaniotaki A., Kubilay, N., and Mihalopoulos, N.: Atmospheric deposition of inorganic phosphorus in the Levantine Basin, easternMediterranean: Spatial and temporal variability and its role in seawater productivity, Limnol. Oceanogr., 48(4), 1557-1568, 2003.

Mayewski, P., Meeker, L. D., Morrison, M. C., Twickler, M. S., Whitlow, S. I., Ferland, K. K., Meese, D. A., Legrand, M. R., and Steffensen, J. P.: Greenland ice core "signal" characteristics: An expanded view of climate change, J. Geophys. Res., 98, 12839 $-12847,1993$.

Mayewski, P. A., Meeker, L. D., Twickler, M. S., Whitlow, S. I., Yang, Q., Lyons, W. B., and Prentice, M.: Major features and forcing of high latitude northern hemisphere atmospheric circulation over the last 110000 years, J. Geophys. Res., 102(C12),
26345-26366, 1997.

Menzel, D. W. and Spaeth, J. P.: Occurrence of ammonia in Sargasso Sea waters and in rain water at Bermuda, Limnol. Oceanogr., 7, 159-162, 1962.

Migon, C., Morelli, J., Nicolas, E., and Copin-Montégut, G.: Evaluation of total atmospheric deposition of $\mathrm{Pb}, \mathrm{Cd}, \mathrm{Cu}$ and $\mathrm{Zn}$ to the Ligurian Sea, Sci. Total Environ., 105, 135-148, 1991.

Migon, C., Sandroni, V., and Béthoux, J. P.: Atmospheric input of anthropogenic phosphorus to the northwest mediterranean under oligotrophic conditions, Mar. Environ. Res., 52(5), 413-426, 2001.

Moy, L. A., Dickerson, R. R., and Ryan, W. F.: Relationship between back trajectories and tropospheric trace gas concentrations in rural Virginia, Atmos. Environ., 28, 2789-2800, 1994.

NEA: National Environment Agency, Ministry of the Environment and Water Resources, Singapore. available at: http://app2.nea. gov.sg/images/Regional_PSI_for_2006.pdf, 2010.

Nielsen, T., Pilegaard, K., Egelarv, A. H., Granby, K., Hummelshøj, P., Jensen, N. O., and Skov, H.: Atmospheric nitrogen compounds: occurrence, composition and deposition, Sci. Total Environ., 189/190, 459-465, 1996.

Poor, N., Pollman, C., Tate, P., Begum, M., Evans, M., and Campbell, S.: Nature and magnitude of atmospheric fluxes of total inorganic nitrogen and other inorganic species to the Tampa Bay Watershed, FL, USA, Water Air Soil Poll., 170, 267-283, 2006.

Prospero, J. M., Barrett, K., Church, T., Dentener, F., Duce, R. A., Galloway, J. N., Levy II, H., Moody, J., and Quinn, P.: Atmospheric deposition of nutrients to the North Atlantic Basin, Biogeochemistry, 35(1), 27-73, 1996.

Pryor, S. C. and Barthelmie, R. J.: Particle dry deposition to water surfaces: processes and consequences, Mar. Pollut. Bull., 41, 220-231, 2000.

Qi, J., Li, P., Li, X., Feng, L., and Zhang, M.: Estimation of dry deposition fluxes of particulate species to the water surface in the Qingdao area, using a model and surrogate surfaces, Atmos. Environ., 39, 2081-2088, 2005.

Reid, J. S. and Hobbs, P. V.: Physical and optical properties of young smoke from individual biomass fires in Brazil, J. Geophys. Res., 103, 32013-32030, 1998.

Reid, J. S., Koppmann, R., Eck, T. F., and Eleuterio, D. P.: A review of biomass burning emissions part II: intensive physical properties of biomass burning particles, Atmos. Chem. Phys., 5, 799825, doi:10.5194/acp-5-799-2005, 2005.

See, S. W., Balasubramanian, R., and Wang, W.: A study of the physical, chemical and optical properties of ambient aerosol particles in Southeast Asia during hazy and non hazy days. J. Geophys. Res., 111, D10S08, doi:10.1029/2005JD006180, 2006.

Seinfeld, J. H. and Pandis, S. N.: Atmospheric Chemistry and Physics: from Air Pollution to Climate Change, 2nd ed, John Wiley, New York, 1203 pp., 2006.

Sehmel, G. A.: Particle and gas dry deposition: a review, Atmos. Environ., 14, 983-1011, 1980.

Slinn, S. A. and Slinn, W. G. N.: Predictions for particle deposition on natural waters, Atmos. Environ., 14, 1013-1016, 1980.

Slinn, W. G. N.: Predictions for particle deposition to vegetative canopies, Atmos. Environ., 16, 1785-1794, 1982.

Spokes, L. J., Yeatman, S. G., Cornell, S. E., and Jickells, T. D.: Nitrogen deposition to the eastern Atlantic Ocean: The importance of south-easterly flow, Tellus, 52B, 37-49, 2000. 
Sundarambal, P., Balasubramanian, R., Karthikeyan, S., and Tkalich, P.: Atmospheric deposition of nutrients and its role on coastal eutrophication in Southeast Asia, in: Advances in Geosciences: Vol. 9- Solid Earth, Ocean Science and Atmospheric Science, edited by: Yun-Tai Chen, World Scientific Publishing Company, Singapore, 149-166, 2006.

Sundarambal, P.: Estimation of the contribution of atmospheric deposition to coastal water eutrophication, Ph.D. Thesis, Department of Chemical and Biomolecular Engineering, National University of Singapore, Singapore, 2009.

Sundarambal, P., Tkalich, P., and Balasubramanian, R.: Impact of biomass burning on ocean water quality in Southeast Asia through atmospheric deposition: eutrophication modeling, Atmos. Chem. Phys., 10, 11337-11357, doi:10.5194/acp-1011337-2010, 2010.

Thingstad, T. F., Zweifel, U. L., and Rassoulzadegan, F.: P limitation of heterotrophic bacteria and phytoplankton in the northwest Mediterranean, Limnol. Oceanogr., 43, 88-94, 1998.

Tkalich, P. and Sundarambal. P.: Eutrophication modelling for the Singapore waters, Singapore Maritime and Port Journal, 122136, 2003.

Turner, D. B.: Comparison of three methods for calculating the standard deviation of the wind direction, J. Climate Appl. Meteor., 25, 703-707, 1986.

van den Berg, A., Dentener, F., and Lelieveld, J.: Modelling the chemistry of the marine boundary layer: Sulfate formation and the role of sea-salt aerosol particles, J. Geophys. Res., 105, 11671-11698, 2000.

Vicars, W. C., Sickman, J. O., and Ziemann, P. J.: Atmospheric phosphorus deposition at a montane site: Size distribution, effects of wildfire, and ecological implications, Atmos. Environ., 44, 2813-2821, 2010.

Wall, S.M., John, W., and Ondo, J. L.: Measurement of aerosol size distribution for nitrate and major ionic species, Atmos. Environ., 22, 1649-1656, 1988.
Wesely, M., and Hicks, B.: A review of the current status of knowledge on dry deposition, Atmos. Environ., 34, 2261-2282, 2000.

Whitall, D., Hendrickson, B., and Paerl, H.: Importance of atmospheric deposited nitrogen to the annual nitrogen budget of the Neuse River estuary, North Carolina, Environ. Int., 29, 393-399, 2003.

William, R. M.: A model for the dry deposition of particles to natural water surfaces, Atmos. Environ., 16(8), 1933-1938, 1982.

Xianren, Q. and Baeyens, W.: The chemical composition of precipitation and atmospheric aerosols in relation to rain water acidity, in: Global and Regional Atmospheric Chemistry, Proceedings of the International Conference on Global and Regional Atmospheric Chemistry, Bejing, China, 622-625, 1990.

Yamartino, R. J.: A comparison of several "single-pass" estimators of the standard deviation of wind direction, J. Climate Appl. Meteor., 23, 1362-1366, 1984.

Yang, H. H., Hsieh, L. T., and Cheng, S. K.: Determination of atmospheric nitrate particulate size distribution and dry deposition velocity for three distinct areas, Chemosphere, 60, 1447-1453, 2005.

Zhang, L., Gong, S., Padro, J., and Barrie, L.: A size-segregated particle dry deposition scheme for an atmospheric aerosol module, Atmos. Environ., 35, 549-560, 2001.

Zhong, Z. C., Victor, T., and Balasubramanian, R.: Measurement of major organic acids in Southeast Asia during burning and nonburning period, Water, Air and Soil Poll., 130(1-4), 457-462, 2001.

Zhuang, H., Chan, C. K., Fang, M., and Wexler, A. S.: Size distributions of particulate sulfate, nitrate, and ammonium at a coastal site in Hong Kong, Atmos. Environ., 33, 843-853, 1999.

Zhang G., Zhang, J., and Liu, S.: Characterization of nutrients in the atmospheric wet and dry deposition observed at the two monitoring sites over Yellow Sea and East China Sea, J. Atmos. Chem., 57, 41-57, 2007. 